\title{
NEW WAY OF CONTROLLING Oryctes monoceros (COLEOPTERA, DYNASTIDAE), A COCONUT PEST IN GHANA
}

\author{
René Philippe ${ }^{1}$ and S.K. Dery ${ }^{2}$
}

By

\begin{abstract}
Oryctes monoceros is one of the most dangerous pests in young coconut and oil palm plantings throughout West Africa.

This species is controlled using different methods that can be applied in combination as part of IPM. The first naturally involves eliminating all larva sites, consisting of dead or felled coconut or oil palm stems. Rapidly covering felled stems with a cover crop can keep the populations of this pest down to a very low level. When adults attack, frequent monitoring of young plantings is recommended, as is the removal of adults from their galleries using a metal mini-harpoon. Chemical control with Lambda-Cyhalothrin reduces damage to seedlings, particularly as that product has good repellent properties. It remains effective for around a month.

Physical control has been developed, using old fishing nets rolled into balls and inserted in the axils of young fronds. This method is highly effective, cheaper than other types of control, does not pollute and is not toxic for handlers. Adults trapped by the rolled up fishing nets, which eventually die, attract other adults that are trapped in turn, thereby increasing the efficiency of the method.
\end{abstract}

Key words: Oryctes monoceros, Coconut, Ghana, Insecticides, Integrated control, fishing net.

1/ CIRAD-CP - TA 80/03 - Avenue Agropolis - 34398 Montpellier Cedex 5 - France

Email: rene.phillippe@cirad.fr

2/ OPRI-CSRI - P.O. Box. 245, Sekondi - Ghana 


\section{INTRODUCTION}

Oryctes monoceros is one of the most dangerous pests in young coconut plantings in Ghana and throughout West Africa (Bedford, 1979; Marcuzzi et al, 1977). The insect lays its eggs and completes its larval cycle in rotting wood, which may be old coconut stems felled for replanting, or the crownless stems of coconut palms killed by Lethal Yellowing disease caused by a phytoplasma. The stems of old oil palms felled for palm wine extraction are also a potential and not insubstantial larval site. Consequently, massive attacks by Oryctes monoceros adults can occur at any time, which is highly prejudicial to the good development of young coconut palms. In fact, the damage caused by this pest can either destroy seedlings, or severely retard their development. In addition, the coconut palm is known to be highly attractive to Oryctes monoceros.

Coconut plantings in Ghana are not large. On average, they have an area of around 1 ha and are highly dispersed. As a cash crop, coconut is the main source of income in the Central region and especially the Western Region of the country. This pest therefore has to be controlled in any programme to replant Ghanaian coconut plantations destroyed by Lethal Yellowing disease, to guarantee good establishment of disease-tolerant coconut hybrids.

Highly diversified control methods have been used to date. Manual control consists in using a mini-harpoon to extract adults that have succeeded in mining a gallery at the base of seedlings. Larvae and pupae are also removed by opening up parts of stems that are already rotten (Mariau, 1993).

If a cover crop is planted, as part of cultural control, fewer adults are attracted and egg-laying by females is thereby reduced. Larval populations are small in stems rapidly covered by Pueraria (Boyé and Aubry, 1973; Mariau and Calvez, 1973).

Chemical control provides satisfactory protection for young coconut palms (Mariau, 1967). Monthly or fortnightly insecticide applications, in the axils of young fronds, such as Carbosulfan mixed with sawdust, or Carbofuran granules, have proved to be effective but very expensive in the long run (Toh and Brown, 1978). Repellent molecules have also been used with a degree of success: Phorate (Jayaraman, 1985) and naphthalene mothballs (Sadakathulla and Ramachandran, 1990; Gurmit Singh, 1987).

Biological control effectively helps to reduce populations of this type of pest in clearly defined environments (Hurpin 1974). Application of Metarhizium anisopliae spores gives good results on Oryctes rhinoceros in the Philippines and Indonesia (Coles, 1991; Darwis, 1990; Latch and Falloon, 1976; Sitepu. et al. 1988). Baculovirus oryctes (formerly Rhabdionvirus oryctes) has been tested in Ivory Coast and Tanzania on Oryctes monoceros without success (Purrini, 1989; Julia and Mariau, 1976). However, that virus is effective against Oryctes rhinoceros in Indonesia and under island climatic conditions (Munaan et al. 1988; Zelazny, 1978). The pheromone of Oryctes monoceros males has been used to attract adults of both sexes into appropriate traps (Morin et al. 1996). However, catches are too small to lead to any rapid reduction in adult populations. In addition, the damage to young coconut palms seems to be greater when traps are installed, as they attract a larger number of adults.

This article sets out to show the results of applying appropriate repellent insecticides to control this pest in Ghana, and to describe the new physical control method recently applied in Ghana to protect young coconut plantings.

\section{Behaviour of Orictes Monoceros Adults}

Only adults of this pest damage coconut and oil palms. The larval instars are found in rotting plant matter, which forms the larval site. In the daytime, adults can be found in feeding galleries made in coconut or oil palms, where they remain for 2 to 11 days. They then leave the feeding galleries via the same entrance hole and return to the larval sites to mate. They are nocturnal and start flying at $6: 30 \mathrm{pm}$, as night falls, until around 9:30 pm. They fly towards the leaf crown of young coconut palms a few months after planting, and prefer to land on the youngest fronds. They then brace themselves against the frond petiole and mine a gallery down to the tender tissues. The spear of an attacked plant is often cut at the base. 
Adults use their mandibles to shear, moving their head up and down, rather than chewing; their horns and the spines on the tibias of their powerful front legs help in the perforation process (Gressitt, 1953).

Adults can mine galleries from a few dozen centimetres long in young coconut palms to more than a metre (46 $\mathrm{cm}$ on average) in older coconut palms (Mariau, 1968).

Unlike Oryctes rhinoceros, the species monoceros is not gregarious. Usually, a single adult is found on a young coconut palm. It is very rare to find a couple of Oryctes monoceros in the same gallery.

The first attack usually occur on coconut palms of a certain height. The smallest palms are very often overlooked by adults. Then, attacks would seem to be more directed at coconut palms that have already been attacked at least once (Bonnot et al. 2003). According to Bedford (1980), the physical effect of the attack makes the tissues of the leaf crown more attractive to adults.

An adult may remain in its feeding gallery for 2 to 11 days before leaving by the entrance hole. Mating usually takes place in larval sites.

Flight is generally limited to a few hundred metres, though that distance can reach $12 \mathrm{~km}$ under certain conditions.

\section{MATERIALS AND METHODS}

The coconut smallholdings, which were around 3 years old, had an average area of one hectare and contained about 160 coconut palms.

Carbosulfan (10 $\mathrm{ml}$ of commercial product per litre of water) was used to impregnate sawdust placed in the axils of young fronds.

Sawdust can be replaced by pieces of coconut husk. In comparison, LambdaCyhalothrin, Cypermethrin + Dimethoate and Endosulfan $(10 \mathrm{ml}$ of commercial product per litre of water) were applied in the same way on young coconut palms. During inspections to determine the effectiveness of the insecticide treatments, dead adults were found in the sawdust, outside the plants, whilst living insects were removed from their feeding galleries.
Pieces of old nylon fishing nets $(30 \mathrm{~cm}$ wide x $50 \mathrm{~cm}$ long) with a $1.7 \mathrm{~cm} \mathrm{x} 1.7 \mathrm{~cm}$ diamond shaped mesh were rolled into balls and stuffed into the axils of all the fronds likely to be attacked by Oryctes monoceros adults. Rolled sheets of old fishing nets (1 $\mathrm{m}$ wide on several metres long according to the height of palms) were also tested by wrapping them around the vertical palm axis, starting from the axil of the lowest frond which is still susceptible to adult Oryctes attacks, up to the spear. The third tested procedure involved enveloping completely the coconut palm with square sheets of old fishing nets: $1 \mathrm{~m} \times 1 \mathrm{~m}$ up to $4 \mathrm{~m} \times 4 \mathrm{~m}$ according to the sizes of the plants.

Using these old fishing nets to control Oryctes came from the idea of inserting a supple physical barrier in the axils of young fronds where attacks frequently occurred. The barrier needed to allow adults to advance easily towards the stem through quite a large mesh, and then quickly block them by overlapping the mesh, which also prevented them from backing out of the trap and escaping. Consequently, in most cases, they could not reach the coconut stem at the frond axil and cause damage. This removable physical barrier in no way harms the coconut palm and is not toxic for handlers.

Sheets of low density polyurethane foam from 5 to $10 \mathrm{~cm}$ thick were tested in $10 \mathrm{~cm}$ wide strips and $10 \mathrm{~cm} \times 10 \mathrm{~cm}$ squares. The polyurethane strips of $10 \mathrm{~cm}$ wide on several metres long according to the palm height were rolled around the vertical axis starting from the lowest frond axil still susceptible to Oryctes attacks, up to the spear. The polyurethane $10 \mathrm{~cm}$ $\mathrm{x} 10 \mathrm{~cm}$ squares were stuffed into the axils of all the fronds susceptible to Oryctes adults' attacks.

\section{RESULTS}

\subsection{Comparison of insecticides and physical barriers \\ a. Cypermethrin + Dimethoate, Lambda- Cyhalothrin and Carbosulfan}


Table 1 shows that lambda-cyhalothrin was not significantly different from carbosulfan, the reference product. It also appeared that lambda-cyhalothrin had a certain repellent effect, as the number of adults found on treated plants was smaller than the number of adults counted in treatments with the other products: carbosulfan, cypermethrin + dimethoate and especially the control. cypermethrin + dimethoate was ruled out, as adult mortality was low throughout the trial, but a large number of adults visited the plants.

\begin{tabular}{|c|c|c|c|}
\hline \multirow[t]{2}{*}{ TREATMENT } & \multicolumn{2}{|c|}{$\begin{array}{c}\text { Number of Oryctes } \\
\text { Adult }\end{array}$} & \multirow{2}{*}{$\begin{array}{l}\text { Adult } \\
\text { Mortality } \\
\text { Percentage }\end{array}$} \\
\hline & Dead & Alive & \\
\hline $\begin{array}{l}\text { Carbosulfan } \\
\text { (28 plants) }\end{array}$ & 13 & 8 & $61.9 \% \mathrm{a}$ \\
\hline $\begin{array}{l}\text { Cypermethrin+ } \\
\text { Dimethoate } \\
((33 \text { plants })\end{array}$ & 11 & 29 & $27.5 \% \mathrm{~b}$ \\
\hline $\begin{array}{l}\text { Lamba- } \\
\text { cyhalothrin } \\
\text { ((22 plants) }\end{array}$ & 8 & 6 & $57.1 \%$ \\
\hline $\begin{array}{l}\text { Control } \\
\text { (30 plants) }\end{array}$ & 0 & 31 & $0 \% \mathrm{c}$ \\
\hline
\end{tabular}

$10 \mathrm{ml}$ of commercial product per litre of water for each insecticide tested - Observation period = approx. 2 months -1 spell of rain 3 weeks after treatment - Student test (0.05)

\section{b. Lambda-Cyhalothrin, Cypermethrin + Dimethoate and old fishing nets}

The results of this second trial with two cypermethrin+dimethoate doses confirmed the limited effectiveness of this insecticide on Oryctes.

The $5 \mathrm{ml}$ lambda-cyhalothrin dose per litre of water was not enough to prevent damage by Oryctes. It was therefore necessary to use 10 $\mathrm{ml}$ per litre of water (Table 2).

The fishing nets gave very promising results. If not too tall, completely enveloping the palms in the nets prevented Oryctes from reaching the plants and some of them were caught in the $1.7 \mathrm{~cm} \mathrm{x} 1.7 \mathrm{~cm}$ mesh. However, one adult did succeed in reaching the plant once
Table 2. Comparison of Insecticides and Old Fishing Nets

\begin{tabular}{|l|c|c|c|}
\hline \multirow{2}{*}{ TREATMENT } & \multicolumn{2}{|c|}{$\begin{array}{c}\text { Number of } \\
\text { Oryctes Adults }\end{array}$} & $\begin{array}{c}\text { Adult } \\
\text { Mortality } \\
\text { Percentage }\end{array}$ \\
\cline { 2 - 4 } & Dead & Alive & $0 \% \mathrm{~b}$ \\
\hline Control (18plants) & 0 & 27 & $85.7 \% \mathrm{a}$ \\
\hline Net over palm (8 plants) & 6 & 1 & $96.6 \% \mathrm{a}$ \\
\hline Net around palm (9plants) & 28 & 1 & $50 \% \mathrm{c}$ \\
\hline $\begin{array}{l}\text { Lambda-cyhalothrin 10ml } \\
\text { (26 plants) }\end{array}$ & 1 & 1 & $0 \% \mathrm{~b}$ \\
\hline $\begin{array}{l}\text { Lambda-cyhalothrin 5 ml } \\
\text { (21 plants) }\end{array}$ & 0 & 4 & $16.7 \% \mathrm{~d}$ \\
\hline $\begin{array}{l}\text { Cypermethrin+dimethoate } \\
10 \mathrm{ml} \text { (20 plants) }\end{array}$ & 1 & 5 & $0 \% \mathrm{~b}$ \\
\hline $\begin{array}{l}\text { Cypermethrin-dimethoate } \\
5 \text { ml (20 plants) }\end{array}$ & 0 & 10 & $\begin{array}{l}\text { Observation period }=1 \text { month 3 weeks - 1 spell of rain around 3 } \\
\text { weeks after treatment student test (0.05) }\end{array}$ \\
\hline
\end{tabular}

it had fallen to the ground, as the net was not pulled right down to the ground. A major drawback was found very soon, as numerous animals (snakes, frogs, birds and crabs) were unexpectedly caught in the nets installed over the palms. The small number of adults caught suggested that coconut palms enveloped in nets lose the silhouette that makes them highly attractive to Oryctes (Figure 1).

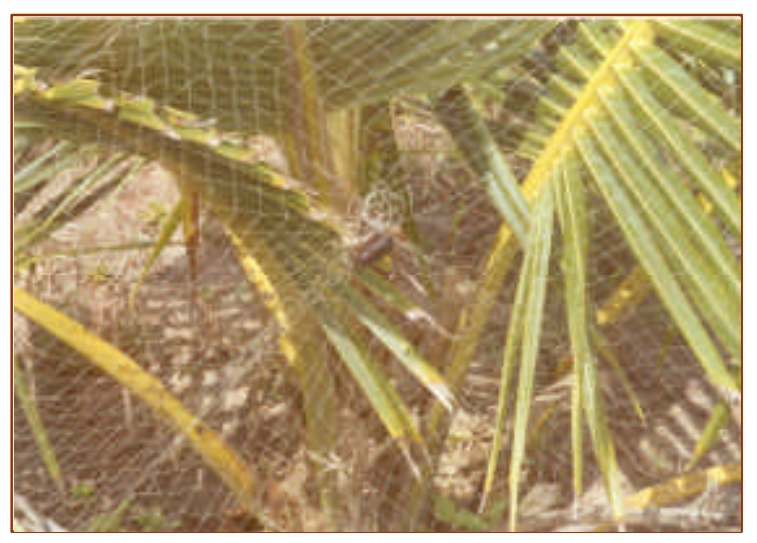

Fig. 1 Old fishing net enveloping

Rolling a section of old fishing net around the vertical axis of a palm, taking care to protect the frond axils from the lowest one which is still susceptible to Oryctes adults attacks. That procedure led to more adults being caught up in the mesh. Some adults managed to pass through some holes that were larger than their bodies. 
Those adults were killed during regular inspections, carried out every three days, and left in place. Other adults were caught on subsequent days on the same palms that already had dead adults in the net surrounding the plant, which were undoubtedly attracted by the smell emanating from their fellow insects (Figure 2).

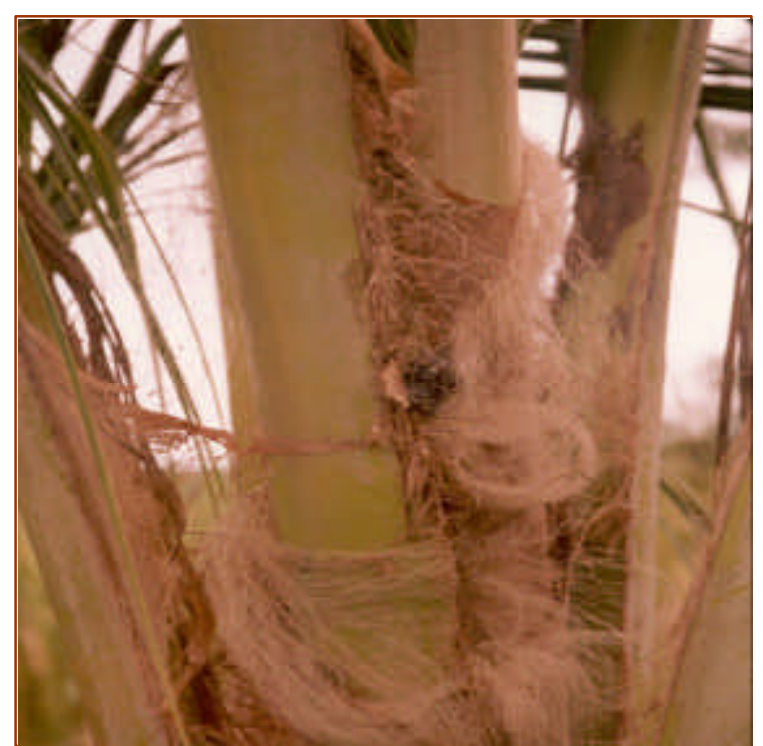

Figure 2. Old fishing net rolled around palm vertical axis from the axils of young fronds

The large number of adults found in the control, and especially when the spiral net installation was used, resulted from the fact that they were repelled from the other palms protected with lambda - cyhalothrin and, to a lesser degree, by cypermethrin+dimethoate. The adults then moved to palms without the insecticide smell: they caused damage on the controls, whilst on the palms with nets the adults were mostly caught, and damage was thereby prevented.

\section{c. Endosulfan and Old Fishing Nets}

Table 3 clearly confirms that the fishing nets effectively protected the coconut palms. During this trial, no attacks were seen on palms protected with old fishing nets. Oryctes.

Endosulfan was not effective against
Table 3. Comparison of insecticide and old fishing nets

\begin{tabular}{|l|c|c|c|}
\hline \multirow{2}{*}{ Treatment } & \multicolumn{2}{|c|}{$\begin{array}{c}\text { Number of Oryctes } \\
\text { adults }\end{array}$} & $\begin{array}{c}\text { Adult } \\
\text { mortality } \\
\text { percentage }\end{array}$ \\
\cline { 2 - 3 } & Dead & Alive & $0 \%$ a \\
\hline Control (18 plants) & 0 & 5 & $100 \% \mathrm{~b}$ \\
\hline $\begin{array}{l}\text { Net over palm } \\
\text { (8 plants) }\end{array}$ & 1 & 0 & $100 \% \mathrm{~b}$ \\
\hline $\begin{array}{l}\text { Net around palm } \\
\text { (13 plants) }\end{array}$ & 11 & 0 & $0 \% \quad \mathrm{a}$ \\
\hline $\begin{array}{l}\text { Endosulfan } 10 \mathrm{ml} \\
\text { (48 plants) }\end{array}$ & 0 & 8 & $0 \% \quad \mathrm{a}$ \\
\hline $\begin{array}{l}\text { Endosulfan } 5 \mathrm{ml} \\
\text { (34 plants) }\end{array}$ & 0 & 3 & \\
\hline
\end{tabular}

Observation period $=3$ weeks - Student test (0.05)

\subsection{Comparison of physical barriers}

\section{a. Old fishing nets and polyurethane foam}

Table 4 shows that fishing nets led to good adult mortality. Those adults caught in the mesh of the nets were considered dead, since they soon did die or were killed by the observers during their inspections. They were left in place, leading to even more adults being caught. This new trapping method was therefore highly effective. The coconut palm itself served as a "trap", since adults had to visit it to feed, combined with the synergy of olfactory stimuli. Trapped adults could no longer reach the stem due to an effective barrier (balled old fishing net), which imprisoned them with no possibility of escape.

Polyurethane foam led to very low or zero mortality. It was initially assumed that adults could not move over that substrate which is perforated with micro-apertures. Sometimes, they managed to bore through the foam, or pass

between the foam and the vertical axis of the coconut palm. However, it was surprising that a $0.5 \mathrm{~cm}$ thick strip of foam gave a better result than a $1 \mathrm{~cm}$ thick strip. There were as many successful attacks with fishing nets as with foam strips and squares. When foam strips were wrapped around the vertical axis of the coconut palms, the palms were visited less by adults. In this case, there would seem to have been a certain repellent effect. 
However, this trial was conducted in a plot of 3-year-old coconut palms. It would be difficult to use foam strips to protect younger palms just after planting.

Table 4. Comparison of old fishing net and foam

\begin{tabular}{|c|c|c|c|}
\hline \multirow[t]{2}{*}{ Treatment } & \multicolumn{2}{|c|}{\begin{tabular}{|c|}
$\begin{array}{c}\text { Number of } \\
\text { Oryctes } \\
\text { adults }\end{array}$ \\
\end{tabular}} & \multirow[t]{2}{*}{$\begin{array}{c}\text { Adult } \\
\text { mortality } \\
\text { percentage }\end{array}$} \\
\hline & Dead & Alive & \\
\hline Control (13 palms) & 0 & 11 & $0 \% \quad \mathrm{a}$ \\
\hline Fishing net balls (35 palms) & 15 & 3 & $83.3 \%$ b \\
\hline $\begin{array}{l}\text { Net around the palm } \\
\text { (46 palms) }\end{array}$ & 25 & 4 & $86.2 \% \mathrm{~b}$ \\
\hline $\begin{array}{l}\text { Foam around the palm } 1 \mathrm{~cm} \\
\text { thick ( } 18 \text { palms) }\end{array}$ & 2 & 6 & $25.0 \% \mathrm{c}$ \\
\hline $\begin{array}{l}\text { Foam around the palm } 0.5 \\
\mathrm{~cm} \text { thick (14 palms) }\end{array}$ & 0 & 2 & $0 \%$ \\
\hline $\begin{array}{l}\text { Inserted square of foam } 1 \mathrm{~cm} \\
\text { thick ( } 9 \text { palms) }\end{array}$ & 0 & 3 & $0 \%$ \\
\hline $\begin{array}{l}\text { Inserted square of foam } 0.5 \\
\mathrm{~cm} \text { thick ( } 25 \text { palms) }\end{array}$ & 0 & 2 & $0 \%$ \\
\hline
\end{tabular}

Observation period $=6$ weeks - Student test (0.05).

\subsection{Generalized installation of old fishing nets as a physical barrier}

\section{a. Three-year-old plot}

Old fishing nets rolled around the palm axis caught slightly more adults and thereby caused slightly greater mortality among adults than old fishing net balls, but the differences were not significant (Table 5).

However, the coconut palms with fishing net balls were slightly less attacked than those with nets rolled around them, but the difference of adult mortality was not significant (Table 5). Consequently, it will be preferable to insert

Table 5. Comparison of balled net and rolled old nets

\begin{tabular}{|c|c|c|c|}
\hline \multirow{2}{*}{ Treatment } & \multicolumn{2}{|c|}{$\begin{array}{c}\text { Number of } \\
\text { Oryctes } \text { adults }\end{array}$} & \multirow{2}{*}{$\begin{array}{c}\text { Adult } \\
\text { mortality } \\
\text { percentage }\end{array}$} \\
\hline & Dead & Alive & \\
\hline $\begin{array}{l}\text { Fishing net balls } \\
\text { (99 palms) }\end{array}$ & 32 & 7 & $82.1 \%$ a \\
\hline $\begin{array}{l}\text { Fishing net rolled } \\
\text { around palm vertical } \\
\text { axis ( } 46 \text { palms) }\end{array}$ & 22 & 3 & $88.0 \%$ a \\
\hline Control (13 palms) & $\overline{0}$ & 13 & $0 \%$ \\
\hline
\end{tabular}

Observation period $=6$ weeks - Student test (0.05) fishing net balls into the axils of fronds that are likely to be attacked, taking care to leave flaps of net extending either side of the leaf bases. This method requires less old net than if the net is rolled right around the vertical axis of the coconut palm (Figure 3).

\section{b. Six month-old plot}

All the palms in this experimental plot were protected with old fishing net balls. Seventy-five percent mortality was obtained after 57 days of observations. Seventeen percent of plants had been successfully attacked. The adults sometimes dropped to the ground and attacked right at the root bulb level. Such attacks, which were often superficial, did not harm the coconut palms.

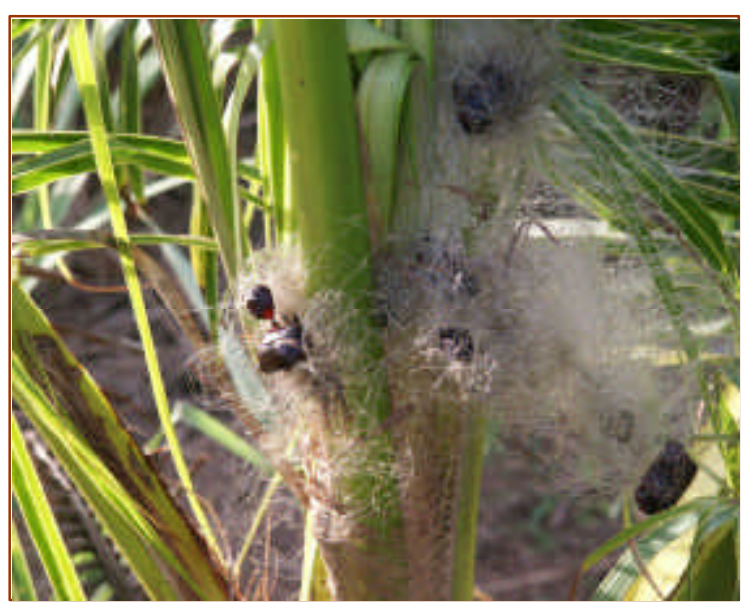

Figure 3. Capture of Oryctes adults with balled old fishing net

\section{c. Estimated cost of protection with old fishing}

This new physical method merely requires a certain quantity of old fishing nets to protect plants throughout the period they are susceptible to Oryctes attacks. As the seedlings develop, it is merely a matter of adding or sometimes moving a few balled fishing net from low fronds to the axils of new fronds (Table 6).

This physical protection method is very effective in protecting coconut palms from Oryctes attacks. Moreover, it is not dangerous for man (no risk of any toxicity) and does not pollute the environment. Lastly, it is cheap when 
compared to chemical control (Table 6). The calculation of treatment costs only takes into account the price of insecticides and of the old fishing nets. Old fishing net prices fluctuate considerably.

\begin{tabular}{|l|l|l|l|l|l|}
\hline \multicolumn{7}{|c|}{ Table 6. Comparison of Different } \\
Against Oryctes monoceros
\end{tabular}

\section{DISCUSSION}

Lambda-cyhalothrin is as effective as the reference product, Carbosulfan. In addition, it repels $O$. monoceros adults. The $\mathrm{LD}_{50}$ for lambda-cyhalothrin is approximately half that of carbosulfan. Consequently, the cost of one litre of lambda-cyhalothrin-based commercial product is half that of a carbosulfan-based product. However, chemical treatments with either of the active ingredients have to be repeated at least every month, especially if it rains within an hour after treatment.

Old fishing nets effectively protect coconut palms from oryctes attacks. The way balled fishing nets are installed in the axils of young fronds is enormously important. The more vigorous the coconut palm, the more it attracts oryctes adults. In that case, careful protection of the basal third of the spear, which can be perforated by adults, is recommended.

Old fishing nets are preferable to new ones, which are very slippery and cannot be easily rolled into balls.

Old fishing nets can easily be obtained from fishermen by offering to exchange them for new ones (5 yards of old net for 4 yards of new).
Badly torn nets can sometimes be recovered for free.

As total protection is very expensive for smallholders, it will be enough initially to install balled fishing net only on palms that have already been attacked once by adults. Indeed, this strategy can be applied since adults are subsequently attracted to plants that have already been injured. Proceeding in this way reduces the cost of installing balled fishing net. Remember that farmers are supposed to inspect their plot at least twice a week in the event of severe attacks.

\section{CONCLUSIONS}

In addition to previously developed control methods, it is possible to recommend an efficient and inexpensive insecticide (lambdacyhalothrin), for both its direct action on the pest itself and for its repellent properties.

Use of old fishing nets rolled into balls and inserted in the axils of young coconut or oil palm fronds is also recommended. This physical method effectively protects coconut and oil palms from oryctes monoceros attacks. It effectively traps and eradicates adults coming preferentially to feed off coconut, and also attracts new arrivals by the smell emanating from adults already trapped in the nets. This method can also be used to control other species of oryctes worldwide. This physical method costs less than the other control techniques. Moreover, it is non-polluting and non-toxic.

\section{REFERENCES}

Bedford, G. O. 1979. Description of the larva of Oryctes monoceros (Olivier) (Coleoptera: Scarabaeidae: Dynastinae) from the Seychelles. Bull. Ent. Res. 69: 599-604.

Bedford, G.O. 1980. Biology, ecology, and control of Palm rhinoceros beetles. Ann. Rev. Entomol. 25: 309-339.

Bonnot, F, and Philippe R. and Dery S.K. 2003. Analysis of repeated oryctes monoceros attacks on coconut in Ghana - Presented at the Seminar "Research on ArthropodPlant Interactions in France: Overview and Prospects" on $30^{\text {th }}-31^{\text {st }}$ January 2003 - INRA -Versailles - Presented also at 
$23^{\text {rd }} \quad$ Biennial Conference "The HIV/AIDS Pandemic: Challenges for the Ghanaian Scientist on 4-7 August 2003.

Boyé, P. and Aubry M. 1973. Replantation des palmeraies industrielles. Méthode de préparation de terrain et de protection contre l'Oryctes en Afrique de l'Ouest. Oléagineux: 28(4); 175-176. - Conseils de l'IRHO no. 127

Coles, R.B. 1991. The current status of Metarhizium anisopliae var. majus to control oryctes rhinoceros in the Philippines. Report of the project PIII/86/004 "Integrated Control of Major Coconut Pests and Diseases", Philippine Coconut Authority: 11, 60p.

Darwis, M. 1990. Minimum effective concentration of Metarhizium anisopliae to control Oryctes rhinoceros. Pemberitaan Penelitian Tanaman Industri (IDN); 25(4): 133-136.

Gressitt, J.L. 1953. The coconut rhinoceros beetle (Oryctes rhinoceros) with particular reference to the Palau Islands. Bull. Bernice Bishop Mus. No. 212, 157pp.

Gurmit, S. 1987. Naphthalene balls for the protection of coconut and oil palms against Oryctes rhinoceros. Planter 63: 286-292.

Hurpin, B. 1974. Lutte biologique contre les Oryctes. Essai en laboratoire de diverses maladies. Oléagineux; 29(3): 135-140.

Jayaraman, V. 1985. Study on repellent action of Phorate against rhinoceros beetle, oryctes rhinoceros Lin. In "Behavioural and Physiological approaches in Pest Management". (Eds. A. Regupathy and S. Jaaraj), TNAU. Coimbatore, pp.116-119.

Julia, J.F. and Mariau, D. 1976. Research on Oryctes monoceros in the Ivory Coast. I. Biological control. The role of the cover plant. Oleagineux: 31(2), pp. 63-68.

Julia, J.F. and Mariau, D. 1976. Recherches sur l'Oryctes monoceros OI. en Côte d'Ivoire. II Essai de lutte biologique avec le virus
Rhabdionvirus oryctes. Oléagineux: 31(3), pp. 113-117.

Latch, G.C.M. and Falloon, R.E. 1976. Studies on the use of Metarhizium anisopliae to control Oryctes rhinoceros. Entomophaga, 21 (1), pp. 39-48.

Marcuzzi, G., Cravera, C. and Faccini, E. 1977. Description of the larva of two litter feeding Scarabeids, Oryctes monoceros and Oryctomorphus bimaculatus. Rev. Ecol. Biol. Sol. 14 (2); pp. 331-341.

Mariau, D. 1967. Lutte chimique contre l'Oryctes. Résultats préliminaires. Oléagineux; 22(3); 155-158.

Mariau, D. 1968. Biologie du comportement alimentaire de l'Oryctes. Oléagineux; 23(6); 377-380.

Mariau, D., and Calvez C. 1973. Méthode de lutte contre l'Oryctes en replantation de palmier à huile. Oléagineux; 28(5): 215218.

Mariau, D. 1993. Lutte intégrée dans les palmeraies: bilan. Oléagineux; 48(7); 309318.

Morin, J.P., Rochat D., Malosse, C., Lettre, M., Desmier de Chenon, R., Wibwo, H. and Descoins, C. 1996. Ethyl 4methyloctanoate, major component of Oryctes rhinoceros (L.) (Coleoptera, Dynastidae) male pheromone. C. R. Acad. Sci. Paris, Life Sciences; 319: pp.595-602.

Munaan A., Lolong A. and Zelazny B., 1988. Long-term effect of Baculovirus release on oryctes rhinoceros populations in central Java. Integrated Coconut Pest Control Project. Coconut Research Institute, Manado, North Sulawesi, Indonesia; pp 114-119.

Purrini, K. 1989. Baculovirus oryctes release into oryctes monoceros population in Tanzania, with special reference to the interaction of virus isolates used in our laboratory infection experiments. Journal of Invertebrate Pathology: 53(3): 285-300. 
Sadakathulla, S. and Ramachandran, T.K. 1990. A novel method to control rhinoceros beetle, Oryctes rhinoceros L. in coconut. Indian Coconut. 21(7-8): 10-12.

Samsudin, A., Chew Poh Soon and Mohd Mat Min. 1963. Oryctes rhinoceros: breeding and damage on oil palm to Oil Palm Replanting Situation. The Planter: 69(813): 583- 591.

Sitepu, D., Kharie S., Waroka J.S. and Motulo H.F.J. 1988. Methods for the production and use of metarhizium anisopliae against Oryctes rhinoceros. Integrated Coconut Pest Control Project - Annual report of Coconut Research Institute - Manado, North Sulawesi, Indonesia, pp.104-111.

Toh, P.Y. and Brown T.P. 1978. Evaluation of carbofuran as a chemical prophylactic control measure for oryctes rhinoceros in young oil palms. Planter: 54: 3-11.

Zelazny, B. 1978. Methods of inoculating and diagnosing the baculovirus disease of oryctes rhinoceros. FAO Plant Prot. Bulletin, 26: 163-168. 